University for Business and Technology in Kosovo

UBT Knowledge Center

UBT International Conference

2012 UBT International Conference

Nov 2nd, 9:00 AM - Nov 3rd, 5:00 PM

\title{
The impact of ICT application in accounting services in Albania
}

\author{
Filloreta Madani \\ University of Vlora, fcenolli@yahoo.com \\ Evelina Bazini \\ University of Vlora, ebazini2001@yahoo.com
}

Follow this and additional works at: https://knowledgecenter.ubt-uni.net/conference

Part of the Business Commons

\section{Recommended Citation}

Madani, Filloreta and Bazini, Evelina, "The impact of ICT application in accounting services in Albania" (2012). UBT International Conference. 57.

https://knowledgecenter.ubt-uni.net/conference/2012/all-events/57

This Event is brought to you for free and open access by the Publication and Journals at UBT Knowledge Center. It has been accepted for inclusion in UBT International Conference by an authorized administrator of UBT Knowledge Center. For more information, please contact knowledge.center@ubt-uni.net. 


\title{
The impact of ICT application in accounting services in Albania
}

\author{
Ph.D Filloreta Madani \\ Head of Finance Department \\ Faculty of Economy, University of Vlore "Ismail Qemali" \\ fcenolli@yahoo.com \\ Prof.As. Evelina Bazini \\ Dean, Faculty of Economy \\ University of Vlora "Ismail Qemali" \\ ebazini2001@yahoo.com
}

\begin{abstract}
Prior to advances in technology, accounting records were maintained only on a manual basis, with the bookkeeper (or possibly the owner) required to complete a manual source document for each sale or receipt, and then spend the evenings or weekends writing the transactions of the day or week in special journals, stock cards, and debtor and creditor records. This obviously took some time, time that would otherwise have been spent operating the business.
\end{abstract}

However, the development of computerized accounting systems has revolutionized the way small businesses keep their accounting records.

This paper conveys the findings of a study conducted to explore how information and communication technologies (ICT) in Albania have changed many aspects of accounting and financial reporting and, as a result, offer new and exciting opportunities to accounting professionals.

Key words: Keywords: accountants; computer usage; e-accounting, ICT infrastructure 